\title{
МОРФОЛОГІЧНІ ЗМІНИ ЕКВІВАЛЕНТА СТРОМИ РОГІВКИ, ОТРИМАНОЇ МЕТОДОМ ДЕЦЕЛЮЛЯРИЗАЦЇ̈
}

Вступ. Використання ксеногенного трансплантаційного матеріалу за сучасних умов широко визнано в різних сорерах медицини. На фоні різкого збільшення людського травматизму, порушення екологічного балансу біосфрери зростає частка патологій рогівки, тому постала проблема дефріциту донорського матеріалу в офртальмології. У зв'язку з дефріцитом донорської людської рогівки та низькою ефективністю ії пересадки при деяких видах рогівкової патології, актуальним є пошук альтернативних матеріалів для кератопластики, що й стало стимулом до пошуку різних методик виготовлення і застосування ксеногенних трансплантатів.

Мета дослідження - вивчити морфрофрункціональні зміни еквівалента строми рогівки, видаленої 3 очей свиней та отриманої методом децелюляризації, з метою подальшої можливості ії застосування як матеріалу для кератопластики.

Методи дослідження. Рогівку, отриману з видалених очей свиней, розміщують у середовищі для культивування тканини, після чого проводять ї децелюляризацію. Обробляють 0,5 \% розчином додецилсульфату натрію при постійному струшуванні; обробляють ультразвуком (тричі), здійснюють інкубацію за присутності фрерментного розчину папаїну; промивають буфрерним розчином (pH 6,5), центрифугують. Поміщають у розчин полівінілпіролідону для зберігання.

Результати й обговорення. Досліджено морфоофункціональний стан еквівалента строми рогівки, отриманої методом децелюляризації. Мікроскопічно в гістологічних препаратах еквівалента строми рогівки, одержаної методом децелюляризації, виявляють деструкцію переднього та заднього епітеліїв рогівки. Поверхня власної речовини обмежена щільною передньою пограничною пластинкою (мембраною Боумена), наявні залишки багатошарового плоского незроговілого епітелію, але епітеліоцити в його складі значно змінені, погано контуруються їх плазмолеми, в набряклій цитоплазмі розташовані пікнотичні, інтенсивно базофрільні ядра. Гістологічні дослідження показали, що у власній речовині рогівки втрачається гомогенність ї̈ структури, сполучнотканинні пластинки розшаровані, власна речовина рогівки набуває сітчастого вигляду. На окремих ділянках гістологічного зрізу децелюляризованої рогівки в просторах між пучками колагенових фрібрил власної речовини мікроскопічно спостерігають деструктивно змінені подовгастої форми фрібробласти, ядра їх інтенсивно базофрільні, цитоплазма не контурується.

Висновки. Гістологічно встановлено, що децелюляризація рогівки призводить до значних змін їі морфологічного стану, пов'язаних із деструкцією клітинного компонента як епітеліальних тканин, так $і$ власної речовини, розволокненням пучків колагену з утворенням сітки. Дані мікроскопічні зміни вказують на ефрективність застосування розробленої методики децелюляризації з метою отримання еквівалента строми ксенорогівки для трансплантації. Подальші розробка та вдосконалення цих методів, ширше впровадження в клінічну практику є одним із найбільш актуальних і перспективних напрямків офртальмотрансплантології.

КЛЮЧОВІ СЛОВА: рогівка свиней; морфологічний стан; децелюляризація; кератопластика.

ВСТУП. За результатами аналізу фрахової літератури, патологія рогівки посідає одне 3 провідних місць серед причин сліпоти і слабкого 3ору [1]

За даними Всесвітньої організації охорони здоров'я, 23 мільйони людей у всьому світі страждають від захворювань рогівки, які призво-

() М. Б. Данилюк, І. М. Кліщ, І. П. Кузьмак, С. Б. Крамар, 2020. дять до часткової, а в 10 мільйонів - до повної втрати зору на одному чи обох очах [2].

Проблеми боротьби зі слабкозорістю та сліпотою актуальні й для України, де захворювання рогівки посідають третє місце, і з кожним роком ситуація з поширеністю кератектазій незмінно погіршується [3, 4].

Деякі хвороби, такі, як трахома, травми та опіки рогівки, кір, бактеріальні інфрекції тощо, $є$ 
провідними причинами сліпоти, яку можна вилікувати шляхом пересадки рогівки. Щорічно у світі проводять лише від 100 до 200 тисяч пересадок рогівки, що вказує на значний дефріцит донорських рогівок для пересадки. У західних країнах існує відносний десріцит донорських рогівок, але у країнах, що розвиваються, спостерігають майже повну їх відсутність. Проблема нестачі донорського рогівкового матеріалу $€$ нагальною для всіх країн, особливо для України . В Україні щорічно потрібно приблизно 4000 рогівок для пересадки, тоді як на рік виконують лише близько 500 пересадок рогівки $[5,6]$.

Одним з основних шляхів лікування хворих із патологією рогівки є кератопластика. В останні роки проведено експериментальні дослідження потенційних можливостей використання для кератопластики свинячої рогівки як такої, що за своїми морфологічними й імунологічними властивостями достатньо наближена до рогівки людини [7].

На даний час пересадка рогівки є найпоширенішою трансплантаційною технологією, але труднощі її реалізації в клініці становлять сутність наукової і практичної проблеми сучасної оортальмології. Це оперативне втручання із самого початку стикалось з такими проблемами як забезпечення повноцінного якісного донорського матеріалу, вдосконалення техніки пересадки, боротьба з так званою хворобою трансплантата, викликаною несумісністю між донором і реципієнтом [7, 8].

Удосконалення методів децелюляризації рогівки тварин з метою отримання біоінженерних зразків для їх подальшої кератопластики дозволяє вирішити актуальну проблему трансплантології - отримання донорського матеріалу [8-13].

Оскільки на даний час не існує надійного, стандартизованого протоколу децелюляризації рогівки людини, наявність зазначених проблем зумовила актуальність проведеного дослідження та визначила мету цієї роботи.

Мета дослідження - вивчити морфоорункціональні зміни еквівалента строми рогівки, видаленої з очей свиней та отриманої методом децелюляризації, з метою подальшої можливості її застосування як матеріалу для кератопластики.

МЕТОДИ ДОСЛІДЖЕННЯ. Технологія отримання донорського матеріалу була стандартною. Забір рогівок проводили в цеху забою тварин 3 дотриманням принципів біоетики відповідно до Загальних етичних принципів експериментів на тваринах (Київ, 2001), узгоджених з положеннями Європейської конвенції про захист хребетних тварин, що використовуються для дослідних та інших наукових цілей (Страсбург, 1986), і Директиви Європейського Союзу 2010/10/63 EU щодо експериментів на тваринах, а також згідно 3 Науково-практичними рекомендаціями з утримання лабораторних тварин та роботи 3 ними [14].

Рогівку, отриману з видалених очей свиней, розміщують у середовищі для культивування тканини, після чого проводять її децелюляризацію таким чином: обробляють 0,5 \% розчином додецилсульфату натрію за умов постійного струшування при температурі, не вищій $4{ }^{\circ} \mathrm{C}$, потім обробляють ультразвуком (використовують ультразвуковий диспергатор УЗДН-М 750) протягом 5 хв, здійснюють інкубацію за присутності ферментного 0,1 \% розчину папаїну (pH 6,5) впродовж 2,5 год при $30{ }^{\circ} \mathrm{C}$, промивають у калій-фросфратному 0,1 м бусрері (pH 6,5) трикратно по 5 хв. Знову обробляють ультразвуком протягом 5 хв, обробляють 0,5 \% розчином додецилсульсрату натрію двічі впродовж 3 год, промивають у калій-фросфатному 0,1 м буфері (pH 6,5) трикратно по 5 хв, ще раз обробляють ультразвуком протягом 5 хв, промивають у калій-фросфатному буфері (pH 6,5) п'ятикратно по 5 хв. Центрифругують (ROTOFIX 32-A) при 3000 g 15 хв 3 декантацією трикратно і переносять у середовище для зберігання - у 2 \% розчин полівінілпіролідону при температурі $0{ }^{\circ} \mathrm{C}$ (Пат. $101707 \mathrm{U}$, 2015) [10].

Для проведення гістологічних досліджень забирали шматочки рогівки, фріксували їх у 10 \% нейтральному формаліні. Подальшу обробку матеріалу з наступною заливкою у парафрінові блоки здійснювали відповідно до загальноприйнятих методик [15]. Отримані за допомогою санного мікротома зрізи товщиною 5-6 мкм забарвлювали гематоксилін-еозином $[15,16]$.

Гістологічні препарати вивчали за допомогою світлового мікроскопа SEO SCAN та фротодокументували з використанням відеокамери Vision CCD Camera із системою виводу зображення 3 гістологічних препаратів.

РЕЗУЛЬТАТИЙ ОБГОВОРЕННЯ. ПровеДЕНі гістологічні дослідження рогівки свиней у нормі підтверджують загальні закономірності структурної організації ії компонентів та подібність до рогівки людини. Мікроскопічно інтактна рогівка вкрита багатошаровим плоским незроговілим епітелієм, що розташовується на гомогенній базальній мембрані. У власній речовині інтактної ксенорогівки наявні кератоцити, які відрізняються за розмірами та фрормою. Крім типових дефінітивних фріброцитів, спостерігали молоді камбіальні клітини-фрібробласти та зрілі фрібробласти з добре розвиненими органелами, що активно 
синтезують компоненти міжклітинної речовини. Ці клітини розміщені між паралельними пучками оксифрільних колагенових волокон. Задній епітелій добре структурований, складається з плоских епітеліоцитів. Гістологічні дані, отримані при вивченні структурної організації ксенорогівки в нормі, були необхідними для проведення порівняльного аналізу з результатами наступних досліджень.

Після здійснення децелюляризації макроскопічно спостерігають помітне потовщення рогівки та її помутніння, що супроводжується повною втратою прозорості й набуттям нею фрарфорово-білого кольору.

Мікроскопічно в гістологічних препаратах, забарвлених гематоксилін-еозином, виявляють деструкцію переднього та заднього епітеліїв рогівки. Поверхня власної речовини обмежена щільною передньою пограничною пластинкою (мембраною Боумена) (рис. 1).

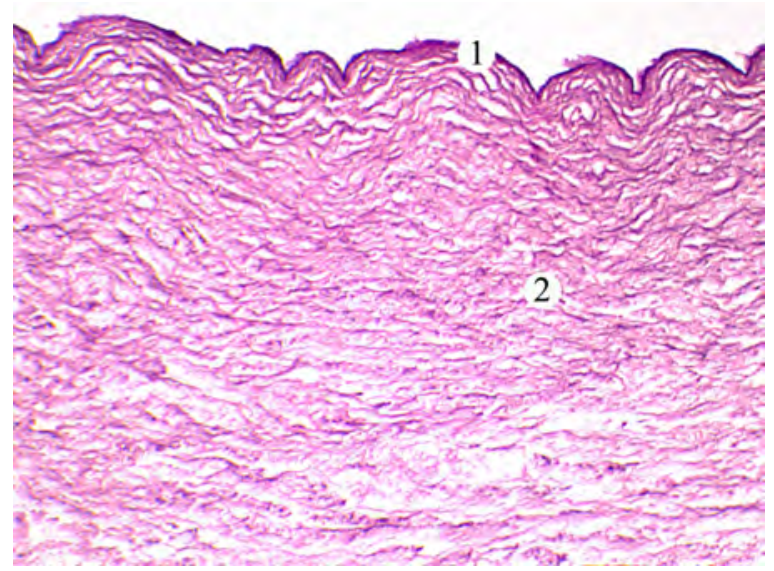

Рис. 1. Гістологічний стан рогівки після процесу децелюляризації: 1 - передня погранична пластинка; 2 власна речовина. Гематоксилін-еозин. $\times 100$.

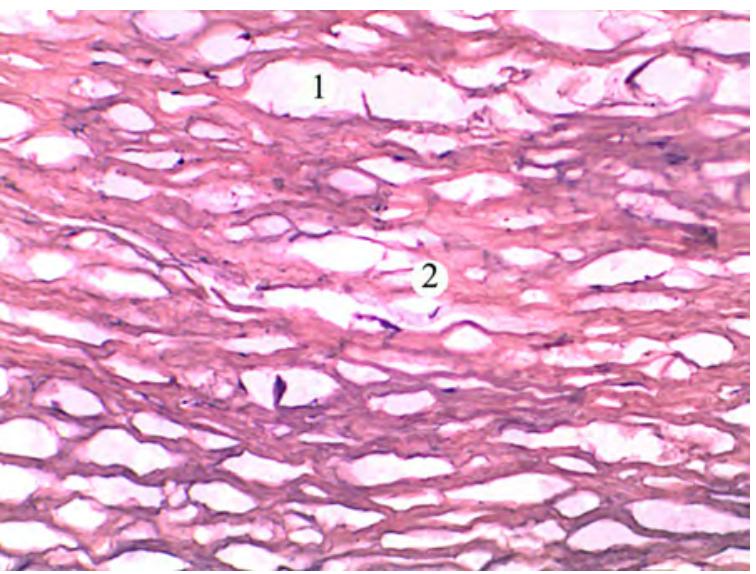

Рис. 3. Гістологічний стан власної речовини рогівки після процесу децелюляризації: 1 - оптично-світлі порожнини між пучками колагенових фрібрил; 2 - колагенові фрібрили. Гематоксилін-еозин. $\times 200$.
У незначних за площею ділянках наявні залишки багатошарового плоского незроговілого епітелію, але епітеліоцити в його складі значно змінені, погано контуруються їх плазмолеми, в набряклій цитоплазмі розташовані пікнотичні, інтенсивно базофрільні ядра (рис. 2).

Гістологічні дослідження показали, що у власній речовині рогівки втрачається гомогенність її структури, сполучнотканинні пластинки розшаровані. Завдяки наявності широких просторів між пучками колагенових фрібрил власна речовина рогівки набуває сітчастого вигляду (рис. 3).

На окремих ділянках гістологічного зрізу децелюляризованої рогівки в просторах між пучками колагенових фрібрил власної речовини мікроскопічно спостерігають деструктивно змінені подовгастої фрорми фрібробласти. Ядра цих клітин інтенсивно базофрільні, цитоплазма не контурується (рис. 4).

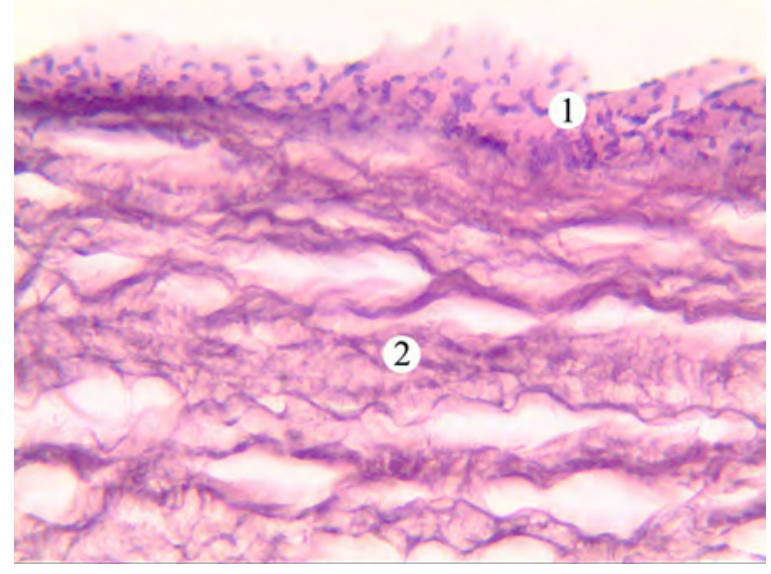

Рис. 2. Мікроскопічні зміни рогівки після процесу децелюляризації: 1 - залишки переднього епітелію; 2 власна речовина. Гематоксилін-еозин. $\times 400$.

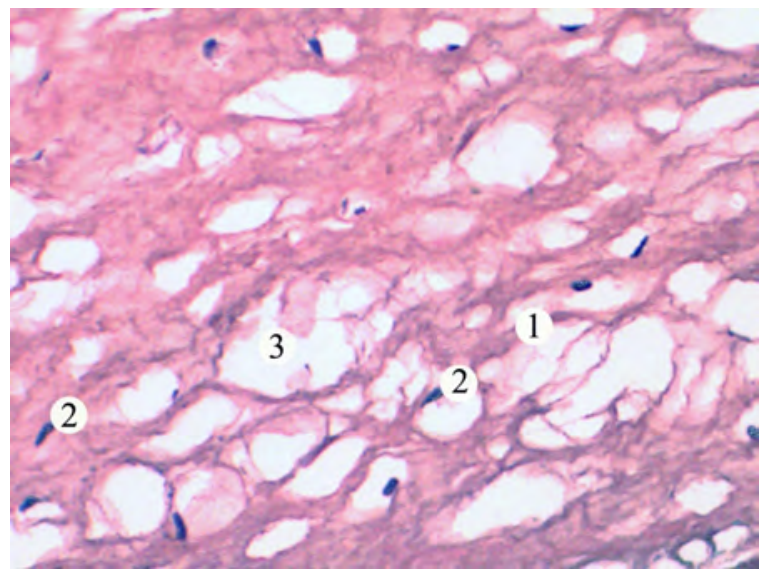

Рис. 4. Мікроскопічні зміни власної речовини рогівки після процесу децелюляризації: 1 - пучки колагенових фрібрил; 2 - деструктивно змінені фрібробласти; 3 - оптичносвітлі простори. Гематоксилін-еозин. ×400. 
ВИСНОВКИ. Гістологічно встановлено, що децелюляризація рогівки призводить до значних змін її морфологічного стану, пов'язаних із деструкцією клітинного компонента як епітеліальних тканин, так і власної речовини, розволокненням пучків колагену 3 утворенням сітки. Дані мікроскопічні зміни вказують на ефективність застосування розробленої методики децелюляризації з метою отримання еквівалента строми ксенорогівки для трансплантації. Подальші розробка та вдосконалення цих методів, ширше впровадження в клінічну практику $є$ одним із найбільш актуальних і перспективних напрямків офтальмотрансплантології.

\section{СПИСОК ЛІТЕРАТУРИ}

1. Савчук 3. Л. Особливості реорганізації структур рогівки кролів з їі хімічним опіком на тлі мерказоліліндукованого гіпотирозу / 3. Л. Савчук, І.М.Кліщ, I. Є. Герасимюк // Journal of Health Sciences. - 2014. № 4 (14). - C. 190-200.

2. Smith D. The epidemiology and diagnosis of penetrating eye injuries / D. Smith, K. Wrenn, L. Stack // Academic Emergency Medicine: Official Journal of the Society for Academic Emergency Medicine. - 2002. - 9, No 3. - P. 209-213. DOI:10.1111/j.1553-2712.2002. tb00246.x.

3. Збитнева С. В. Захворюваність населення України на хвороби ока та його придаткового апарату [Електронний ресурс] / С. В. Збитнева // Вісн. соціальної гігієни та організації охорони здоров'я України. 2010. - № 3. - С. 14-17. - Режим доступу : http://nbuv. gov.ua/UJRN/VSG_2010_3_4.

4. Слабкий Г. О. Рівень задоволеності потреби населення України у трансплантації рогової оболонки [Електронний ресурс] / Г. О. Слабкий, С. В. Збітнєва // Вісн. соціальної гігієни та організації охорони здоров'я України. - 2013. - № 4 (58). - С. 21-23. - Режим доступу : http://nbuv.gov.ua/UJRN/VSG_2013_4_6.

5. Основные проблемы офртальмотрансплантологии и возможные пути их решения [Электронный ресурс] / Н. Г. Завгородняя, О. А. Исакова, Н. С. Луценко [и др.] // Медицина сьогодні і завтра. - 2011. № 1-2. - С. 78-81. - Режим доступа : http://nbuv.gov. ua/UJRN/Msiz_2011_1-2_20.

6. Пасєчнікова Н. В. Оортальмологічна допомога населенню України в 2009 році / Н. В. Пасєчнікова, С. О. Риков, Г. І. Степанюк // Офтальмол. журн. 2010. - № 5. - С. 83-88.

7. Турчин М. В. Експериментальне обґрунтування і досвід використання ксенорогівки при лікувально-тектонічній кератопластиці у хворих із виразками рогівки різної етіології / М. В. Турчин, Н. В. Пасєчнікова // Шпитальна хірургія. Журн. імені Л. Я. Ковальчука. 2017. - № 4 (80). - C. 43-48.

8. Corneal decellularization: A method of recycling unsuitable donor tissue for clinical translation? / S. L. Wilson, L. E. Sidney, S. E. Dunphy [et al.] // Current Eye
Research, - 2016. - No. 41 (6). - P. 769-782. DOI: 10.3109/02713683.2015.1062114.

9. Pasyechnikova N. V. Experimental study of efficacy of intralamellar keratoplasty with corneal stromal substitute developed from decellularized porcine cornea / N. V. Pasyechnikova, B. M. Cogan, S. G. Kolomiichuk // J. Ophthalmol. (Ukraine) - 2017. - No. 3 - P. 48-55. DOI: 10.31288/oftalmolzh201734855.

10. Деклараційний патент на корисну модель № 101707, 25.09.2015 МПК(2006.01) A61F9/01, A61P27/02, A61N7/02 (2006.01). Спосіб отримання еквівалента строми рогівки для кератопластики / Коган Борис Михайлович, Пасєчнікова Наталія Володимирівна, Насінник Ілля Олегович, Коломійчук Сергій Григорович. Власник : Державна установа “Інститут очних хвороб і тканинної терапії ім. В. П. Філатова НАМН України". - № u2015032153 ; заявл. 06.04.15 ; опубл. 25.09.15, Бюл. № 18/2015.

11. Fernandez-Perez J. Decellularization and recellularization of cornea: Progress towards a donor alternative // J. Fernandez-Perez, M. Ahear // Methods. 2020. -171.-P.86-96. DOI:10.1016/j.ymeth.2019.05.009.

12. Decellularization methods for developing porcine corneal xenografts and future perspectives / A. Isidan, Sh. Liu, P. Li [et al.] // Xenotransplantation. - 2019. - 26, Issue 6. - P. 12564. DOI: 10.1111/xen.12564.

13. Global survey of corneal transplantation and eye banking / P. Gain, R. Jullienne, Z. He [et al.] // JAMA Ophthalmol. -2016. -134(2)-P. 167-173. DOI:10.1001/ jamaophthalmol.2015.4776.

14. Науково-практичні рекомендації з утримання лабораторних тварин та роботи з ними / Ю. М. Кожем'якін, О. С. Хромов, М. А. Філоненко, Г. А. Сайфеетдінова. - К. : Авіцена, 2002. - 155 с.

15. Сорочинников А. Г. Гистологическая и микроскопическая техника / А. Г. Сорочинников, А. Е. Доросевич. - М. : Медицина, 2007. - 448 с.

16. Горальський Л. П. Основи гістологічної техніки і морфоорункціональні методи досліджень у нормі та при патології : навч. посіб. / Л. П. Горальський, В. Т. Хомич, О. І. Кононський. -2-ге вид. -Житомир : Полісся, 2011. - 288 c. 


\section{REFERENCES}

1. Savchuk, Z.L., Klishch, I.M., \& Herasymiuk, I.Ye. (2014). Osoblyvosti reorhanizatsii struktur rohivky kroliv z yii khimichnym opikom na tli merkazolil-indukovanoho hipotyrozu [Features of the reorganization of the structures of rabbit horns from the chemistry on the mercazolyl-induced hypothyrosis]. Zhurnal medychnykh nauk Journal of Health Sciences, 4 (14), 190-200 [in Ukrainian]. DOI:\%2010.5281/zenodo.13349.

2. Smith D., Wrenn K., \& Stack L. (2002). The epidemiology and diagnosis of penetrating eye injuries. Academic Emergency Medicine: Official Journal of the Society for Academic Emergency Medicine, 9 (3), 209-213. DOI:10.1111/j.1553-2712.2002.tb00246.x.

3. Zbytneva, S.V. (2010). Zakhvoriuvanist naselennia Ukrainy na khvoroby oka ta yoho prydatkovoho aparatu [Incidence of eye diseases and its appendages in the population of Ukraine]. Visnyk sotsialnoi hihiieny ta orhanizatsii okhorony zdorovia Ukrainy-Bulletin of Social Hygiene and Health Care Organization of Ukraine, 3, 14-17 [in Ukrainian].

4. Slabkyi, H.O., \& Zbitnieva, S.V. (2013). Riven zadovolenosti potreby naselennia Ukrainy u transplantatsii rohovoi obolonky [The level of satisfaction of the needs of the population of Ukraine in corneal transplantation]. Visnyk sotsialnoi hihiieny ta orhanizatsii okhorony zdorovia Ukrainy - Bulletin of Social Hygiene and Health Care Organization of Ukraine, 4 (58), 1-23 [in Ukrainian]. http://nbuv.gov.ua/UJRN/VSG_2013_4_6.

5. Zavhorodniaia, N.H., Ysakova, O.A., \& Lutsenko, N.S. (2011). Osnovnye problemy oftalmotransplantologii i vozmozhnye puty ikh resheniya [The main problems of ophthalmic transplantology and possible solutions]. Medytsyna sohodni i zavtra - Medicine Today and Tomorrow, 1-2, 78-81 [in Russian]. Retrieved from: http://nbuv.gov.ua/UJRN/Msiz_2011_1-2_20.

6. Pasechnikova, N.V. (2010). Oftalmologicheskaya pomoshch naseleniyu Ukrainy v 2009 godu [Ophthalmic care to the Ukrainian population in 2009]. Oftalmologicheskiy zhurnal - Ophthalmologic Journal, 5, 83-88 [in Russian].

7. Turchin, M.V., \& Pasechnikova, N.V. (2017). Eksperymentalne obHuntuvannia i dosvid vykorystannia ksenorohivky pry likuvalno-tektonichnii keratoplastytsi u khvorykh iz vyrazkamy rohivky riznoi etiolohii [Experimental substantiation and experience of using xenocorneal in medical-tectonic keratoplasty in patients with corneal ulcers of different etiology]. Shpytalna khirurhiia. Zhurnal imeni L. Ya. Kovalchuka - Hospital Surgery. Journal named by L. Ya. Kovalchuk, 3, 43-48 [in Ukrainian].

8. Wilson, S.L., Sidney, LE., Dunphy, S.E., Dua, H.S., \& Hopkinson, A. (2016). Corneal decellularization: A method of recycling unsuitable donor tissue for clinical translation? [Detselyulyaryzatsiia rohivky: metod pe rerobky neprydatnoyi donors'koyi tkanyny dlya klinichnoho perekladu?]. Potochni doslidzhennia ochei-Current Eye Research, 41, 6, 769-782 DOI: 10.3109/02713683.2015. 1062114 [in Ukrainian].

9. Pasyechnikova, N.V., Cogan, B.M., \& Kolomiichuk, S.G. (2017) Experimental study of efficacy of intralamellar keratoplasty with corneal stromal substitute developed from decellularized porcine cornea. J. Ophthalmol. (Ukraine), 3, 48-55. DOI: 0.31288/oftalmolzh201734855.

10. Declarative patent for a utility model No. 101707, 25.09.2015 IPC (2006.01) A61F9 / 01, A61R27 / 02, A61N7 / 02 (2006.01) [Deklaratsiinyi patent na korysnu model № 101707, 25.09.2015 MPK(2006.01) A61F9/01, A61R27/02, A61N7/02 (2006.01)]. Sposib otrymannia ekvivalenta stromy rohivky dlia keratoplastyky. Kohan Borys; Pasiechnikova Nataliia; Nasinnyk Illia; Kolomiichuk Serhii. Vlasnyk: Derzhavna ustanova "Instytut ochnykh khvorob i tkanynnoi terapii im. V.P. Filatova NAMN Ukrainy", zaiavka № u2015032153 vid 06.04.2015. Patent opublikovano 25.09.2015, biul. № 18/2015 [in Ukrainian].

11. Julia Fernández-Pérez, J., \& Ahearne, M. (2020). Decellularization and recellularization of cornea: Progress towards a donor alternative. Methods, 171, 86-96. DOI:10.1016/j.ymeth.2019.05.009.

12. Abdulkadir, I., Shaohui, L.P., \& Burcin, E. (2019). Decellularization methods for developing porcine corneal xenografts and future perspectives. Xenotransplantation, 26 (6), e12564. DOI: 10.1111/xen.12564.

13. Gain, P., Jullienne, R., \& He, Z. (2016). Global survey of corneal transplantation and eye banking. JAMA Ophthalmol.,134 (2), 167-173. DOI:10.1001/jamaophthalmol.2015.4776.

14. Kozhemiakin, Yu.M., Khromov, O.S., Filonenko, M.A., \& Saifetdinova, H.A. (2002). Naukovo-praktychni rekomendatsii z utrymannia laboratornykh tvaryn ta roboty z nymy [Scientific and practical advice on keeping laboratory animals and work with them]. Kyiv: Avitsena [in Ukrainian].

15. Sorochinnikov, A.G., \& Dorosevich, A.E. (2002). Gistologicheskaya i mikroskopicheskaya tekhnika [Histological and microscopic technique]. Moscow: Meditsina [in Russian].

16. Horalskyi, L.P., Khomych, V.T., \& Kononskyi, O.I. (2011). Osnovy histolohichnoi tekhniky i morfofunktsionalni metody doslidzhen u normi ta pry patolohii [Histological and microscopic technique]. Zhytomyr: Polissia [in Ukrainian]. 


\title{
МОРФОЛОГИЧЕСКИЕ ИЗМЕНЕНИЯ ЭКВИВАЛЕНТА СТРОМЫ РОГОВИЦЫ, ПОЛУЧЕННЫЕ МЕТОДОМ ДЕЦЕЛЮЛЯРИЗАЦИИ
}

\begin{abstract}
Резюме
Вступление. Использование ксеногенного трансплантационного материала в современных условиях широко признано в различных сфрерах медицины. На фроне резкого увеличения человеческого травматизма, нарушения экологического баланса биосферы растет доля патологий роговицы, поэтому возникла проблема дефицита донорского материала в офтальмологии. В связи с дефицитом донорской человеческой роговицы и низкой эфрфективностью ее пересадки при некоторых видах роговичной патологии, актуальным является поиск альтернативных материалов для кератопластики, что и стало стимулом к поиску различных методик изготовления и применения ксеногенных трансплантатов.

Цель исследования - изучить морфофункциональные изменения эквивалента стромы роговицы, удаленной с глаз свиней и полученной методом децелюляризации, с целью дальнейшей возможности ее применения в качестве материала для кератопластики.

Методы исследования. Роговичу, полученную из удаленных глаз свиней, размещают в среде для культивирования ткани, после чего проводят ее децелюляризацию. Обрабатывают 0,5 \% раствором додецилсульфата натрия при постоянном встряхивании; обрабатывают ультразвуком (трижды), осуществляют инкубацию в присутствии орерментного раствора папаина; промывают буоерным раствором (рН 6,5), центрифругируют. Помещают в раствор поливинилпирролидона для хранения.

Результаты и обсуждение. Исследовано морфофункциональное состояние эквивалента стромы роговицы, полученной методом децелюляризации. Микроскопически в гистологических препаратах эквивалента стромы роговицы, полученной методом децелюляризации, выявляют деструкцию переднего и заднего эпителиев роговицы. Поверхность собственного вещества ограничена плотной передней пограничной пластинкой (мембраной Боумена), есть остатки многослойного плоского неороговевающего эпителия, но эпителиоциты в его составе значительно изменены, плохо контурируются их плазмолемы, в отечной цитоплазме расположены пикнотичные, интенсивно базофильные ядра. Гистологические исследования показали, что в собственном веществе роговицы теряется гомогенность ее структуры, соединительнотканные пластинки расслоенные, собственное вещество роговицы приобретает сетчатый вид. На отдельных участках гистологического среза децелюляризованной роговицы в пространствах между пучками коллагеновых фрибрилл собственного вещества микроскопически наблюдают деструктивно измененные продолговатой фрормы фрибробласты, ядра их интенсивно базофильные, цитоплазма не контурируется.

Выводы. Гистологически установлено, что децелюляризация роговицы приводит к значительным изменениям ее морфологического состояния, связанным с деструкцией клеточного компонента как эпителиальных тканей, так и собственного вещества, разволокнением пучков коллагена с образованием сетки. Данные микроскопические изменения указывают на эффективность применения разработанной методики децелюляризации с целью получения эквивалента стромы ксенороговицы для трансплантации. Дальнейшие разработка и совершенствование этих методов, более широкое внедрение в клиническую практику являются одним из наиболее актуальных и перспективных направлений офтальмотрансплантологии.
\end{abstract}

КЛЮЧЕВЫЕ СЛОВА: роговица свиней; морфологическое состояние; децелюляризация; кератопластика.

M. B. Danyliuk, I. M. Klishch, I. P. Kuzmak, S. B. Kramar I. HORBACHEVSKY TERNOPIL NATIONAL MEDICAL UNIVERSITY

\section{MORPHOLOGICAL CHANGES IN THE EQUIVALENT OF THE CORNEA STROMA OBTAINED BY THE DECELULARIZATION METHOD}

\section{Summary}

Introduction. Diseases and injuries of the cornea are a major cause of vision impairment and blindness. Currently, the best treatment for restoring vision in patients with corneal blindness is transplantation with donor- 
derived corneal tissue. Decellularized corneas are among the most promising materials for engineering corneal tissue since they replicate the complex structure and composition of real corneas. Decellularization is a process that aims to remove cells from organs or tissues resulting in a cell-free scaffold consisting of the tissues extracellular matrix. Due to the deficiency of the donor human cornea and the low efficiency of its transplantation in some types of corneal pathology, the search for alternative materials for keratoplasty is relevant, which has stimulated the search for different methods of manufacturing and using xeogenic grafts.

The aim of the study - to learn the morphofunctional changes of the equivalent of the stroma of the cornea, removed from the eyes of pigs and obtained by the method of decelularization in order to further its use as a material for keratoplasty.

Research Methods. The corneal membrane obtained from the removed eyes of pigs is placed in a tissue culture medium, after which it is decelerized. Treated with $0.5 \%$ solution of sodium dodecyl sulfate with constant shaking; treated with ultrasound (three times), incubate in the presence of an enzyme solution of papain; washed with buffer solution ( $\mathrm{pH}$ 6.5), centrifuged. Place in a solution of polyvinylpyrrolidone for storage.

Results and Discussion. The morphofunctional state of the equivalent of the corneal stroma obtained by the method of decelularization was studied. Microscopically in histological preparations of the equivalent of the corneal stroma obtained by the method of decelularization, the destruction of the anterior and posterior epithelium of the cornea is detected. The surface of its own substance is limited by a dense anterior border plate (Bowman's membrane), there are remnants of multilayered squamous non-keratinized epithelium. Histological examinations showed that the homogeneity of its structure is lost in the corneal's own substance, the connective tissue plates are stratified, and the corneal's own substance acquires a reticular appearance. In some areas of the histological section of the decelularized cornea in the spaces between the bundles of collagen fibrils of its own substance, destructively altered oblong fibroblasts are microscopically observed, their nuclei are intensely basophilic, the cytoplasm is not contoured.

Conclusions. Thus, it is histologically established that the decelularization of the cornea leads to significant changes in its morphological state, associated with the destruction of the cellular component of epithelial tissues and the defibering of collagen bundles of substantia propria with the formation of a network. These microscopic changes indicate that the use of developed technique of decelularization is effective to obtain the equivalent of the xenocorneal stroma for transplantation. Further development and improvement of these methods, wider introduction into clinical practice is one of the most relevant and promising areas of ophthalmotransplantology.

KEY WORDS: pig cornea; morphological condition; decelularization; keratoplasty.

Отримано 05.11.20

Адреса для листування: І. П. Кузьмак, Тернопільський національний медичний університет імені І. Я. Горбачевського мОЗ України, майдан Волі, 1, Тернопіль, 46001, Україна, e-mail: kuzmak@tdmu.edu.ua. 